\title{
Economic evaluation of single-pill combination of indapamide and amlodipine in the treatment of arterial hypertension in the Polish setting
}

\author{
Paweł Kawalec ${ }^{1}$, Przemysław Holko ${ }^{2}$, Ewa Stawowczyk ${ }^{3}$, Łukasz Borowiec $^{4}$, Krzysztof J. Filipiak ${ }^{5}$ \\ 1Departament of Drug Management, Institute of Public Health, Faculty of Health Sciences, Jagiellonian University Collegium Medicum, \\ Krakow, Poland \\ ${ }^{2}$ HTA Centre Sp. z o.o. Sp. komandytowa, Krakow, Poland \\ ${ }^{3} \mathrm{HTA}$ expert, Krakow, Poland \\ ${ }^{4}$ Medical Department, Servier Poland Ltd., Warsaw, Poland \\ ${ }^{51 \text { st }}$ Department of Cardiology, Medical University of Warsaw, Warsaw, Poland
}

\begin{abstract}
Background: Arterial hypertension is a common disorder that affects around 9 million adults in Poland. Single-pill combinations (SPCs) for the treatment of arterial hypertension have significant advantages over the free combinations, resulting in lower risk of cardiovascular events and lower consumption of medical resources. The current ESC/ESH 2013 guidelines for the first time recommend treatment with a combination of thiazide-like diuretic with calcium channel blocker. Currently, no such combination is reimbursed from public funds in Poland.
\end{abstract}

Aim: To assess the economic value of treatment with SPC of indapamide and amlodipine (Tertens-AM ${ }^{\circledR}$ ) for hypertensive patients compared with free combination therapy (FC), in the Polish setting.

Methods: As there are currently no published data directly estimating the additional effect of using indapamide + amlodipine SPC vs. FC, two extreme approaches are presented: with difference in effectiveness due to improved adherence to the treatment estimated from published studies on other molecules used in hypertension such as SPCs and FCs - the base-case approach (1); and assuming no difference of effectiveness or adherence between SPC and FC of indapamide and amlodipine - the conservative approach (2). Modelling was carried out based on the Markov process in lifetime horizon. In the base-case approach, with the difference in effectiveness between SPC and FC, it was assumed that the differences in compliance translate into the differences in systolic blood pressure. Patients' characteristics were correlated with the risk of events associated with cardiovascular disease, based on the prediction algorithms from the Framingham Heart Study. Costs were considered from a National Health Fund (NHF) perspective and NHF and patient's perspective, and therefore direct medical costs were only included.

Results: The treatment with SPC of indapamide and amlodipine in place of FC resulted in 7.6 additional days of life in full health and longer overall patient survival by 2.9 days. The replacement of FC with SPC would result in national savings from both NHF perspective and NHF and patient's perspective, irrespective of the assumption of the difference in adherence between SPC and FC. The savings would amount to 1.602-3.954 million PLN and 16.498-19.186 million PLN from NHF perspective and NHF and patient's perspective, respectively.

Conclusions: The treatment with SPC of indapamide and amlodipine for hypertensive patients was found to be dominant over FC or at least less expensive than treatment with FC when the difference in effectiveness was neglected. The replacement of FC with SPC would result in savings from both NHF perspective and NHF and patient's perspective.

Key words: indapamide, amlodipine, single-pill combination, health economics, cost-utility analysis, budget impact analysis

Kardiol Pol 2015; 73, 9: 768-780

\section{Address for correspondence:}

Paweł Kawalec, MD, PhD, Institute of Public Health, Faculty of Health Sciences, Jagiellonian University Collegium Medicum, ul. Grzegorzecka 20, $31-531$ Kraków, Poland, e-mail: mxpkawal@cyf-kr.edu.pl

Received: 22.12.2014 Accepted: 31.03.2015

Available as AoP: 28.04 .2015

Copyright (๑) Polskie Towarzystwo Kardiologiczne 


\section{INTRODUCTION}

Arterial hypertension affects around 9 million adults in Poland [1]. The prevalence, at $30 \%$ of undiagnosed hypertension and $9 \%$ of diagnosed but untreated hypertension, was revealed by preliminary results of the NATPOL 2011 study (data unpublished, personal communication, NATPOL 2011 Group). The new hypertension guidelines published by the European Society of Cardiology/European Society of Hypertension (ESC/ESH) widely recommend treating patients with two different hypertensive drugs, introducing for the first time diuretic-calcium channel blocker combination [2]. For such therapy single-pill combinations (SPCs; also known as fixed-dose combinations indicating two or more active substances administrated in one formulation) have significant advantages over free combinations (FCs; active substances administrated at the same doses in separate formulations), i.e. higher persistence and compliance, simplification of the therapeutic scheme, stronger hypertensive effect, and lower therapy costs. The newly published experts' consensus of the Polish Cardiac Society and the Polish Society of Hypertension strongly promote SPC over FC, underlying better compliance, persistence, and adherence to treatment when using SPC and not FC on a regular basis. This paper advises Polish doctors to use SPC preferably and as such is unique in Europe [3].

Despite the above advantages of SPC over FC [4], resulting in lower risk of cardiovascular events and lower consumption of medical resources [5-7], and contrary to experts' consensus, widespread use of SPC is uncertain. Only certain SPCs for the treatment of arterial hypertension are reimbursed in Poland (amiloride + hydrochlorothiazide, candesartan + hydrochlorothiazide, cilazapril + hydrochlorothiazide, lisinopril + amlodipine, lisinopril + hydrochlorothiazide, losartan + hydrochlorothiazide, perindopril + amlodipine, perindopril + indapamide, ramipril + felodipine, ramipril + hydrochlorothiazide, telmisartan + hydrochlorothiazide, valsartan + hydrochlorothiazide). However, none of them contains a combination of thiazide-like diuretic and calcium channel blocker. Although head-to-head clinical trials comparing the effects of indapamide or chlorthalidone with hydrochlorothiazide (HCTZ) are not available, indirect comparisons and post hoc analyses suggest that the use of chlorthalidone or indapamide is associated with a reduction in cardiovascular events [8], which is not the case for HCTZ. It is worth noting that the majority of SPCs containing the diuretic component currently reimbursed in Poland are based on hydrochlorothiazide, which is not reimbursed as a separate treatment option; it is also noted as inferior compared to indapamide by some guidelines (e.g. the National Institute for Health and Clinical Excellence, www.nice.org. uk/guidance/CG127).

The SPC of indapamide and amlodipine was examined in our study. The only medicine registered in Poland containing SPC of indapamide and amlodipine is Tertens-AM ${ }^{\circledR}$
(Les Laboratoires Servier), which is available in two dosages: $1.5 \mathrm{mg}$ of indapamide $+5 \mathrm{mg}$ of amlodipine and $1.5 \mathrm{mg}$ of indapamide $+10 \mathrm{mg}$ of amlodipine. According to the annual sales data provided by the National Health Fund (NHF, nfz. gov.pl) $388,221,728$ unit doses (5 mg or $10 \mathrm{mg}$ ) of amlodipine and 444,685,884 unit doses (1.5 mg) of indapamide were reimbursed by the NHF in 2013 . Thus, the market potential of SPC of indapamide and amlodipine is up to 13 million units containing 30 doses in theory, and around one third of this value in practice. Hence an assessment of the economic value of the intervention, which could affect up to 350 thousand of individuals in Poland, was required. There was a need for economic evaluations of hypertension treatment with SPC of indapamide and amlodipine in the Polish setting.

To estimate the economic value of treatment with SPC of indapamide and amlodipine for hypertensive patients a cost-utility analysis was performed.

As there is no data directly indicating that the SPC of indapamide and amlodipine will result in higher effectiveness in comparison with FC (data available for other SPCs only), the economic evaluation was carried out in the framework of two extreme assumptions: with difference in effectiveness due to difference in adherence to the treatment, and without difference of effectiveness or adherence between SPC and FC of indapamide and amlodipine.

\section{METHODS}

The population of this study complies with the registered indication for the use of Tertens-AM ${ }^{\circledR}$ (substitution treatment of patients with essential hypertension, who use indapamide and amlodipine at the same doses in separate formulations; summary of product characteristics, Terens-AM ${ }^{\circledR}$, Poland).

Baseline patients' characteristics were based on the results of the POZ-NAD study of 74,745 patients from Poland with the objective to characterise patients with arterial hypertension under hypertensive treatment [9]. Missing characteristics, as well as other inputs unavailable from the literature, were based on the results of a survey among experts from four medical centres in Poland (section A of Table 1).

\section{Structure of economic model}

Modelling was carried out based on a Markov-type cohort simulation process and implemented in Microsoft Excel 2007 (Microsoft Corporation, Redmond, WA). The timeframe was a lifetime with a cycle length of a month during the first 300 cycles and a year afterwards to balance the functionality and precision of the model. The observation of two hypothetical cohorts of patients with arterial hypertension was performed. The starting point was the beginning of SPC treatment in the study arm and continuation of treatment with FCs in the control arm. Thus the optimal moment of transition to the SPC was assumed in the study arm (normalisation of arterial pressure or at least a significant reduction in the pressure 
Table 1. Input variables of economic model

$\begin{array}{lcr}\text { Variable } & \text { Value } \mathbf{( 9 5 \% ~ C l )} & \text { Source and assumptid } \\ \text { A. Patients characteristics } & & \\ \text { Age at baseline [years] } & 59.70(37.16-82.24) & \text { POZ-NAD [9] } \\ \text { Females } & 0.585(0.472-0.693) & \text { POZ-NAD [9] } \\ \text { Nicotine users } & 0.221(0.135-0.321) & \text { POZ-NAD [9] } \\ \text { Total cholesterol [mg/dL] } & 217.50(133.81-301.19) & \text { POZ-NAD [9] } \\ \text { HDL cholesterol [mg/dL] } & 54.60(14.22-94.98) & \text { POZ-NAD [9] } \\ \text { Patients with diabetes mellitus } & 0.233(0.145-0.335) & \text { POZ-NAD [9] } \\ \text { Obese patients } & 0.437(0.327-0.550) & \text { POZ-NAD [9] } \\ \text { Post-stroke patients at baseline } & 0.081(0.031-0.152) & \text { POZ-NAD [9] } \\ \text { Patients with CVD at baseline } & 0.542(0.429-0.653) & 0.225(0.069-0.440)\end{array}$

Patients with left ventricular hypertrophy

$0.225(0.069-0.440)$

Patients requiring $5 \mathrm{mg}$ dose of amlodipine

$0.409(0.236-0.594)$

(others: $10 \mathrm{mg} / \mathrm{d}$ )

Mean SBP at baseline $[\mathrm{mmHg}]$

134.60 (SD 22.68)

B. Probability of CVD event modifiers

RR of stroke/TIA after other CVD event

$1.55(1.17-2.07)$

1

$1.30(1.10-1.60)$

$2.04(0.52-8.02)$

HR of subsequent stroke/TIA

C. Hypertensive drug utilisation measures (base-case scenario)

Probability of adherence (MPR or PDC $\geq 0.8$ )

among patients treated with FCs

OR for adherence to treatment with SPCs vs. FCs

$1.68(1.41-2.00)$

Mean MPR among adherent patients

0.831 (range: 0.8-1)

Mean MPR among non-adherent

0.388 (range: $0-0.8$ )

D. Determinants of effectiveness

Change in SBP on treatment with SPCs vs. FCs

$-4.10(-9.80$ to 1.50$)$

[mm Hg] (base-case analysis)

Change in SBP on treatment with SPCs vs. FCs

$-5.30(-6.50$ to -4.10$)$

[mm Hg] (sensitivity analysis)

Change in SBP after subsequent medicine addition

(ARBs) [mm Hg]

$-8.74(-10.05$ to -7.44$)$

E. Health-related utility weights (base-case scenario)

Utility weights for general population

Age-dependent

Utility decrement for hypertension

Utility weight for stroke/TIA

0.022 (range: 0-0.05)

$0.70(0.67-0.73)$

$0.73(0.69-0.76)$
Survey of experts from 4 medical centres

Survey of experts from 4 medical centres

Iskenderov et al. [10]

D'Agostino et al. [15] and O'Donnell et al. [16] Assumption of no impact since no data was identified Morrow et al. $[17,18]$

Meta-analysis of Howard et al. [19] and Bergh et al. [20]

Meta-analysis of FC arm of observational studies included in meta-analysis by Gupta et al. [21] updated to April 2014 (manuscript in preparation)

Meta-analysis performed by Gupta et al. [21] updated with 6 studies (manuscript in preparation)

Brixner et al. [22]

Brixner et al. [22]

Meta-analysis of 9 studies

by Gupta et al. [21]

Results of recent large observational study

by Bronsert et al. [25]

Meta-analysis of Oparil et al. [12] and Calhoun et al. [13]

Golicki et al. [26]

Sullivan et al. [33], Wang et al. [34], Burström et al. [35]

Lunde et al. [27]

De Smedt et al. [28]; data for Polish patients only

\section{F. Proportion of the main reason for hospitalisation of patients with CVD event other than stroke/TIA}

Acute coronary syndrome

$0.438(0.403-0.541)$

Angina pectoris or PAD

Congestive heart failure
$0.312(0.284-0.320)$

$0.250(0.175-0.277)$
Survey of experts from 4 medical centres in Poland Survey of experts from 4 medical centres in Poland Survey of experts from 4 medical centres in Poland 
Table 1. (cont.) Input variables of economic model

\begin{tabular}{|c|c|c|}
\hline Variable & Value $(95 \% \mathrm{Cl})$ & Source and assumptions \\
\hline \multicolumn{3}{|l|}{ G. Other variables } \\
\hline Time to treatment modification, months & $22(14-30)$ & Survey of experts from 4 medical centres in Poland \\
\hline Probability of dying & Age-dependent & $\begin{array}{l}\text { Life expectancy tables of Poland } 2012 \text { from } \\
\text { Central Statistical Office (stat.gov.pl) }\end{array}$ \\
\hline Days in hospital - stroke/TIA & 7.20 & $\begin{array}{c}\text { DRG statistics for } 2013 \text { (prog.nfz.gov.pl); average length of } \\
\text { hospitalisation for relevant DRGs }\end{array}$ \\
\hline Days in hospital - other CVD events & 4.51 & $\begin{array}{c}\text { DRG statistics for } 2013 \text { (prog.nfz.gov.pl); average length of } \\
\text { hospitalisation for relevant DRGs }\end{array}$ \\
\hline
\end{tabular}

ARB - angiotensin receptor blocker; Cl — confidence intervals; CVD — cardiovascular disease; DRG — Diagnosis Related Group; FC — free combination; HDL — high density lipoprotein; HR — hazard ratio; MPR — medication possession ratio; OR — odds ratio; PAD — peripheral arterial disease; PDC — proportion of days covered; RR — risk ratio; SBP — systolic blood pressure; SD — standard deviation; SPC — single-pill combination; TIA - transient ischaemic attack

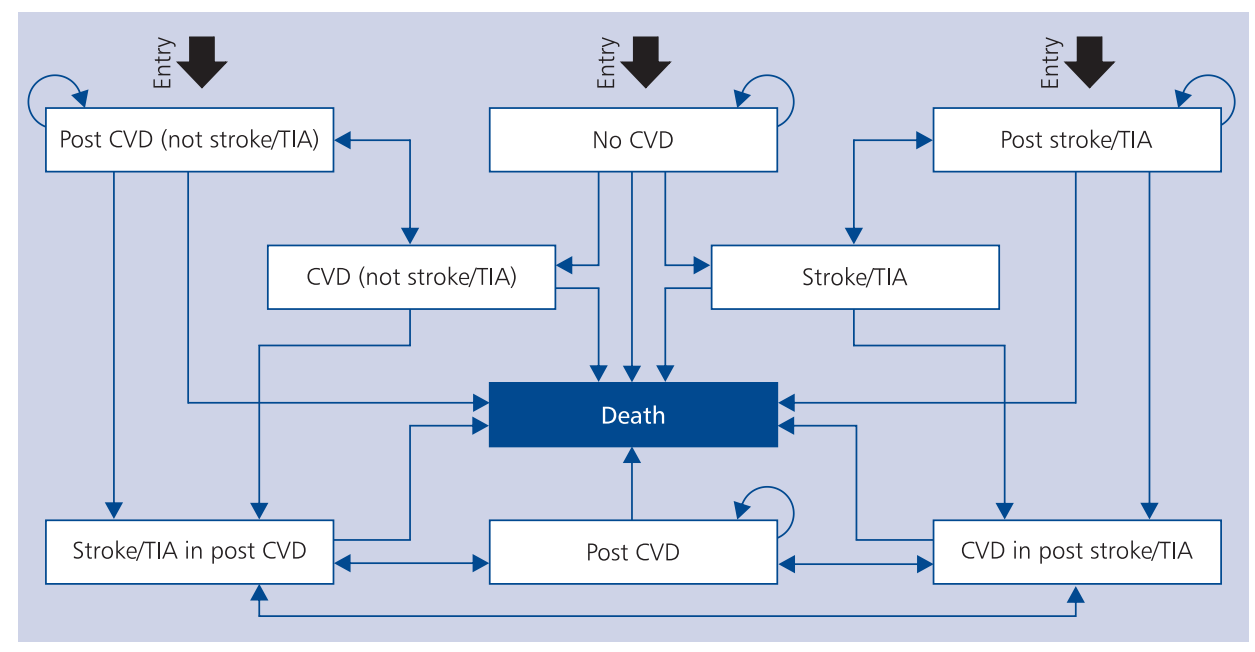

Figure 1. Structure of the Markov model; CVD — cardiovascular disease; TIA — transient ischaemic attack

under treatment with separate products of indapamide and amlodipine at doses equal to the ones in SPC). The simplified structure of the model is presented in Figure 1. Each cohort enters the model via 'no CVD' (cardiovascular disease), 'post CVD' (not stroke/TIA) (transient ischaemic attack), or 'post stroke/TIA' state depending on the patient's condition at baseline. In subsequent cycles, a patient can transfer to the clinical states associated with inpatient care of cardiovascular events; remain in its current state; transfer to states of history of cardiovascular events (after each event); or transfer to the absorbing state 'Death'. The model allowed for the determination of the patient's medical history, i.e. the proportion of patients with each CVD (stroke or TIA, acute coronary syndrome, angina pectoris, peripheral arterial disease, congestive heart failure), which enabled us to precisely estimate the health outcomes as well as costs associated with cardiovascular events.

Mean systolic blood pressure (SBP) at baseline was based on the trial of 89 patients with II degree arterial hypertension by Iskenderov et al. [10]. The average SBP after 24 weeks of treatment with FC of indapamide and amlodipine was used to inform the model, according to a defined starting point of modelling (after initial assessment of the efficacy and safety of the FC). The scenario considered differences in the effectiveness of SPC and FC assuming that the difference in adherence to the treatment and gradual loss of control over arterial pressure (as a result) would be apparent among patients from the compared arms - an increase in SBP would be observed with its magnitude dependent only on the level of adherence to treatment. The change of SBP each cycle was modelled with constant values of other biochemical measures (e.g. total cholesterol or high-density lipoprotein cholesterol) to eliminate potential secondary effects of arterial pressure reduction and hence the multiplication of the additional health effects of the SPC. The model considered observation of deterministic values of patients' characteristics with the exception of SBP, which was observed as a stochastic variable to assess the proportion of patients requiring treatment modification when a significant increase in arterial pressure 
due to non-adherence to treatment and no possibility to perform any action to improve the adherence to treatment (e.g. lack of knowledge, failure to provide information to the physician) was encountered. After a specific period of treatment (22 months in base case) among the proportion of the cohort without control of arterial pressure (SBP > $140 \mathrm{~mm} \mathrm{Hg}$ among patients younger than 60 years or $>150 \mathrm{~mm} \mathrm{Hg}$ among others, according to the recommendations of the Eighth Joint National Committee [11]) the modification of treatment regiment was assumed. The addition of angiotensin receptor blocker (ARB) to current treatment was considered, mainly due to identification of efficacy data for triple therapy with ARBs $[12,13]$. The addition of candesartan, eprosartan, irbesartan, losartan, telmisartan, or valsartan with the amount of each based on the national sales data of reimbursement medicines in 2013 (NHF Announcements) was modelled.

For each cycle the patients' characteristics were correlated with the risk of events associated with CVD (stroke/TIA, other cardiovascular events, or death due to CVD), based on the prediction algorithms from the Framingham Heart Study [14]. Acknowledging the risk assessment tool relates primarily to patients without CVD at baseline, and in clinical practice CVD affects around $60 \%$ of the patients undergoing treatment for hypertension [9]; the increased risk of subsequent events associated with CVD were estimated based on the results of published studies (section B of Table 1) [15-20].

\section{Utilisation of SPCs and FCs}

There are several estimators of adherence (compliance) to treatment, i.e. medication possession ratio (MPR) and proportion of days covered (PDC). Each of these estimators has been interpreted as the proportion of doses taken as prescribed in our study. The standard definition of patient adherent to treatment was adopted, i.e. patients for whom MPR or PDC was calculated at $\geq 0.8$.

To assess the difference in adherence to treatment with SPCs in comparison to FCs the meta-analysis performed by Gupta et al. [21] was updated. An additional search of medical databases was performed in April 2014. Seven additional studies were identified (details will be provided in a separate study). The updated meta-analysis indicated that the likelihood of adherence to the treatment (MPR or PDC $\geq 0.8$ ) with SPCs increases by an odds ratio (OR) of 1.68 in comparison with FCs (95\% confidence intervals [Cl] 1.41-2.00; manuscript in preparation). The probability of adherence to treatment with FCs was estimated via a meta-analysis of the relevant arm of observational studies incorporated in the updated Gupta et al. meta-analysis [21]. The probability of adherence in the SPCs arm was calculated using both variables. Using the probability of adherence in each arm and average MPR among adherent and non-adherent patients from Brixner et al. [22] (the only data source identified), the expected average proportion of days on recommended treatment with SPCs or
FCs was calculated. The variables relating to the utilisation of hypertensive medicines are presented in section C of Table 1.

Whereas the base-case estimation method of consumption of hypertensive medicines is limited by the availability of one source of information on average MPR/PDC among adherent and non-adherent patients, the direct estimation of average MPR/PDC during treatment with SPCs and FCs from Ferrario et al. [7], Dickson et al. (PMID: 18507275), and Yang et al. (PMID: 20629600) was tested in a sensitivity analysis.

\section{Determinants of effectiveness}

There are no data to quantitatively correlate the level of adherence to treatment with health outcomes in hypertensive patients. Available information indicating the impact of SPC treatment on the risk of CVD events [6, 7] or indicating a difference in that risk between patients adherent and non-adherent to hypertensive treatment [23, 24] applies only to specific groups of patients and cannot be generalised to the total population of patients with arterial hypertension. We used SBP as the only predictor of different health outcomes between patients treated with SPCs and FCs mainly because results of the Framingham Heart Study, which indicated a higher prediction capability of this measure than diastolic blood pressure when assessing both as a continuous variables [14], and to create a framework for the assessment of SPCs in specific subgroups of patients with arterial hypertension (the algorithms used in our study could be easily incorporated in future simulations that could assess the value of SPCs in subgroups of patients). In the absence of empirical data on the impact of adherence on the achieved SBP (e.g. the impact of omission of an adequate number of doses of hypertensive medicines on the achieved SBP), the difference in SBP between treatment with SPCs and FCs was assessed using the results of the meta-analysis performed by Gupta et al. [21] in a base case. The update of the systematic review (April 2014) did not reveal any additional studies of SPCs and FCs with reduction of SBP as an endpoint. In sensitivity analysis the difference in SBP achieved under treatment with SPCs and FCs was assessed using the results of a recent large observational study by Bronsert et al. [25].

The impact of the addition of subsequent medicine was based on the results of a meta-analysis of two clinical trials that assessed the efficacy of triple therapy $[12,13]$. Since the addition applied only to the share of patients with evaluated SBP, discretisation of continuous probability distribution of SBP was performed to assess the average SBP among patients successfully treated with SPCs or FCs and among patients requiring additional SBP-lowering boosters. The additional reduction of SBP resulting from $\mathrm{ARB}$ addition was applied to the others only.

The variables related to the efficacy of hypertensive medicines in the reduction of SBP are presented in section D of Table 1. 


\section{Health-related quality of life}

Utilities for the health states represented in the model were based on a scale from 0 to 1 , with 0 representing death and 1 denoting a state of perfect health. Utility weights for the Polish general population reported by Golicki et al. [26] were used to assess the age-related deterioration in quality of life. When the impact of CVD on quality of life was assessed, data from studies of Polish patients or patients with similar characteristics, the results of measurements relating to the quality of life for at least several months from clinical events and the results relating to a total population of patients with a relevant clinical events (e.g. in the case of stroke - the quality of life of patients with stroke or TIA) were preferred. Thus initial reduction in quality of life due to CVD events was not considered in our analysis.

The systematic review was performed to obtain information on utility weights of hypertensive and CVD patients. The search yielded 475 records with at least 17 providing data that could be incorporated in the analysis (data not shown). Several quality of life studies and reviews were identified; however, the results of two studies [27, 28] were considered in base-case analysis according to the criteria described above (section E of Table 1).

\section{Cost input and assumptions}

Costs were considered from a NHF perspective, and NHF and patient's perspective, and therefore direct medical costs were only included. Costs were presented in 2014 Polish zloty (PLN).

The cost of indapamide and amlodipine in FC treatment was based on the official, fixed-unit prices of reimbursed medicines containing those substances at relevant doses $(1.5 \mathrm{mg}$ of indapamide and $5 \mathrm{mg}$ or $10 \mathrm{mg}$ of amlodipine per tablet), weighted by sales data in 2013 reported by the NHF (Polish Ministry of Health regulations and NHF announcements, 2014).

The cost of Tertens-AM ${ }^{\circledR}$ was based on the average retail price observed in May-July 2014 (www.osoz.pl, accessed July 2014). In order to perform an analysis from the perspective of the NHF the reimbursement of SPC was assumed within a separate limit group and 30\% patient co-payment, based on the regulations of the Reimbursement Law (Journal of Laws 2011, no 122, item. 696, as amended) also confirmed by the recent recommendation of the President of the Polish Agency for Health Technology Assessment (HTA) (No. 205/2014, aotm.gov.pl). The calculation of the unit cost from the perspective of the NHF requires a drug that designate a refund limit, i.e. a maximal price of a unit in a specific group of medicines. Based on the Act of May 12, 2011 for reimbursement of medicines, we assumed that the SPC containing $5 \mathrm{mg}$ of amlodipine would set the limit, i.e. the SPC with a lower price of a unit dose and expected market share higher than 15\%, according to the results of a survey among clinical experts and actual sales of $5 \mathrm{mg}$ and $10 \mathrm{mg}$ unit doses of amlodipine.
The average cost of reimbursed ARB weighted by sales data in 2013 was considered. The consumption of medical resources among patients with CVD was based on the results of a survey among experts from four medical centres in Poland. The unit cost of medical resources was based on the Polish tariffs for medical services from June 2014 according to relevant decrees of the President of the NHF (nfz.gov.pl) and actual unit prices of reimbursed medical products according to relevant decree of the Minister of Health.

The results of the cost analysis (Table 2) were validated by the results of published studies and/or country-specific statistics (prog.nfz.gov.pl).

\section{Economic analysis}

We calculated the differences in a lifetime's discounted costs and benefits measured in life years and quality-adjusted life years (QALYS). The primary outcome of this simulation study was the incremental cost-utility ratio (ICUR) of the treatment with SPC of indapamide and amlodipine in place of FC therapy, expressed as an incremental cost per QALY saved. The ICUR was calculated as the difference in total costs from each economic perspective divided by the difference in effectiveness in QALYS.

We consider treatment with SPC to be 'dominant' if resulting in lower lifetime costs and higher QALYs in comparison to treatment with FC, and 'dominated' if resulting in higher total costs and lower QALYS (ICUR $<0$ at both conditions). Willingness to pay (WTP) to obtain additional QALY was established as three times the Gross Domestic Product per capita, following the regulations specific to Poland. In 2014, the threshold value was officially calculated at 111,381 PLN. This threshold was used to appraise the value of SPC therapy, when differences in effectiveness between SPC and FC were faced.

In the conservative scenario assuming no difference in adherence to the treatment and thus no difference in effectiveness, the difference in costs was used to appraise the value of SPC therapy ("cost-minimisation" approach).

All study results were presented per one patient in a lifetime horizon. The costs and health outcomes were discounted at $5 \%$ and $3.5 \%$ annual rates, respectively.

The analysis was performed following the recommendations of the Polish Agency of HTA Act of May 12, 2011 for reimbursement of medicines (Journal of Laws 2011, no 122, item 696) and the Regulation of the Ministry of Health on minimum requirements to be met by Health Technology Assessment (Journal of Laws 2012, item 388).

\section{Sensitivity analysis}

Sensitivity analyses to evaluate the robustness of our findings were conducted.

One-way deterministic sensitivity analyses were performed over the specified range of uncertainty derived from the literature $(95 \% \mathrm{Cl})$ or over the assumed range of uncertainty (Tables 1, 2). The one variable (change in SBP 
Table 2. Mean values of cost variables (in PLN) with 95\% confidence intervals in brackets

\begin{tabular}{|c|c|c|}
\hline Variable & NHF & Patient \\
\hline \multicolumn{3}{|c|}{ Hypertensive treatment (per month of treatment with $100 \%$ adherence): } \\
\hline 1.5 mg indapamide and 5 mg amlodipine (Tertens-AM ${ }^{\circledR} ; \mathrm{SPC}$ ) & 12.83 & 5.50 \\
\hline 1.5 mg indapamide and 10 mg amlodipine (Tertens-AM $\left.{ }^{\circledR} ; S P C\right)$ & 12.83 & 7.11 \\
\hline $1.5 \mathrm{mg}$ indapamide (FC) & 5.47 & 5.09 \\
\hline 5 mg amlodipine (FC) & 5.32 & 5.31 \\
\hline 10 mg amlodipine (FC) & 10.52 & 7.11 \\
\hline ARBs (subsequent line) & 10.76 & 7.08 \\
\hline $\begin{array}{l}\text { Monitoring of treatment (outpatient visits, routine consultations, } \\
\text { and diagnostic tests) }\end{array}$ & $23.02(12.75-36.28)$ & 0 \\
\hline \multicolumn{3}{|l|}{ CVD (per event): } \\
\hline Stroke/TIA & $5996.15(4819.15-7299.82)$ & 0 \\
\hline Acute coronary syndrome & 7543.05 (4116.58-11,989.91) & 0 \\
\hline Angina pectoris or PAD & $2597.13(1570.31-3878.07)$ & 0 \\
\hline Congestive heart failure & 4614.35 (1544.03-9335.37) & 0 \\
\hline \multicolumn{3}{|l|}{ Additional post CVD treatment (per month): } \\
\hline Stroke/TIA & $52.76(26.99-87.02)$ & $66.12(41.49-96.39)$ \\
\hline Acute coronary syndrome & $67.35(49.18-88.34)$ & $51.08(35.50-69.44)$ \\
\hline Angina pectoris or PAD & $58.19(36.61-84.69)$ & $34.46(25.23-45.10)$ \\
\hline Congestive heart failure & $47.87(33.29-65.04)$ & $35.27(27.44-44.06)$ \\
\hline
\end{tabular}

ARB - angiotensin receptor blocker; CVD — cardiovascular disease; FC — free combination; NHF — National Health Fund; PAD — peripheral arterial disease; SPC — single-pill combination; TIA — transient ischaemic attack

achieved between SPCs and FCs treatment) was excluded from the one-way sensitivity analysis since the 'no difference in effectiveness' scenario was presented in base case.

Multivariate deterministic sensitivity analyses incorporating alternative sources of model input data (i.e. utility weights and SPCs/FCs drug utilisation measures) as well as a different structural assumption of the model (i.e. discounting at different rates) were performed.

\section{RESULTS \\ Base-case analysis}

The results of base-case analysis are presented in Table 3. The treatment with SPC of indapamide and amlodipine in place of FC resulted in 7.6 additional days of life in full health and longer overall patient's survival by 2.9 days.

Despite the relatively small clinical effect per patient, the clinical benefits can be significant and clinically relevant if we take into account the entire population of hypertensive patients; moreover, the additional days of life are just and only due to the use of SPC in place of FC. What is more, the use of SPC instead of FC is more comfortable for patients and less costly, thus generating savings.

Despite the assumption regarding the difference in effectiveness, the treatment with SPC of indapamide and amlodipine was found to be less expensive than treatment with FC from both the NHF perspective and the NHF and patient's perspec- tive. The lower average unit cost of SPC resulted in lower total cost from both economic perspectives in comparison with FC when the difference in effectiveness was excluded. Lower average unit cost of SPC and lower cost of CVD treatment, even with the higher utilisation of antihypertensive medicines due to higher adherence to treatment, resulted in lower total cost from both economic perspectives in comparison with FC when the difference in effectiveness was included.

Thus, the treatment with SPC of indapamide and amlodipine was found to be dominant over FC, or at least less expensive than treatment with FC, when the difference in effectiveness was ignored.

\section{Sensitivity analyses}

The sensitivity analyses confirmed the stability of the conclusions of the primary analysis. The one-way sensitivity analyses of variables having the highest impact on ICER are presented in Figure 2. The scenarios of multivariate sensitivity analyses having the highest impact on results of model are presented in Table 4. Other variables and other scenarios of multivariate sensitivity analyses did not change the results of the model outside the range of $\pm 20 \%$ of the base-case results (data not shown).

None of the sensitivity analyses revealed SPC to not be cost-effective in comparison with FC with WTP at 111,381 PLN. Alternative scenarios of SPC and FC utilisa- 
Table 3. Results of base-case analysis (discounted)

\begin{tabular}{|c|c|c|c|c|c|}
\hline Endpoint & $\begin{array}{l}\text { SPC with higher } \\
\text { adherence (1) }\end{array}$ & $\begin{array}{l}\text { SPC with the same } \\
\text { adherence (2) }\end{array}$ & $\mathrm{FC}(3)$ & $\begin{array}{l}\text { Difference } \\
\text { (1 vs. } 3 \text { ) }\end{array}$ & $\begin{array}{c}\text { Difference } \\
\text { (2 vs. } 3 \text { ) }\end{array}$ \\
\hline \multicolumn{6}{|l|}{ Health outcomes: } \\
\hline Life years & 14.4428 & 14.4348 & 14.4348 & 0.0080 & 0.0000 \\
\hline Quality-adjusted life years & 9.4448 & 9.4240 & 9.4240 & 0.0208 & 0.0000 \\
\hline \multicolumn{6}{|c|}{ Cost from NHF perspective, in PLN: } \\
\hline SPC or FC & 1218.26 & 1107.87 & 1197.01 & 21.25 & -89.14 \\
\hline Other, direct medical & 9868.59 & $10,050.92$ & $10,050.92$ & -182.33 & 0.00 \\
\hline Total & $11,086.85$ & $11,158.79$ & $11,247.93$ & -161.08 & -89.14 \\
\hline \multicolumn{6}{|c|}{ Cost from NHF and patient's perspective, in PLN: } \\
\hline SPC or FC & 1830.92 & 1665.02 & 2186.71 & -355.79 & -521.69 \\
\hline Other, direct medical & $14,264.55$ & $14,492.47$ & $14,492.47$ & -227.92 & 0.00 \\
\hline Total & $16,095.47$ & $16,157.49$ & $16,679.18$ & -583.71 & -521.69 \\
\hline
\end{tabular}

FC — free combination; NHF — National Health Fund; SPC — single-pill combination

Mean MPR among non-adherent (0-0.8)

Discount rate for cost $(0-0.1)$

Percentage of patients requiring $5 \mathrm{mg}$ dose of amlodipine $(95 \% \mathrm{Cl})$

Age at baseline $(95 \% \mathrm{Cl})$

Discount rate for health outcomes (0-0.05)

OR for adherence to treatment with SPCs vs. FCs (95\% Cl)

Cost of acute coronary syndrome event $(95 \% \mathrm{Cl})$

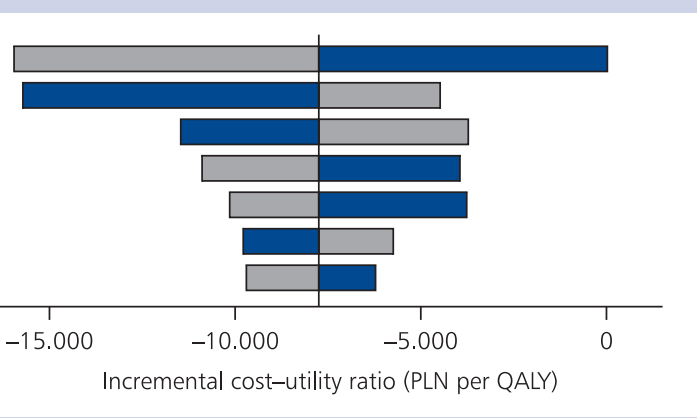

A $\square$ Upper and $\square$ Lower limit of variable value

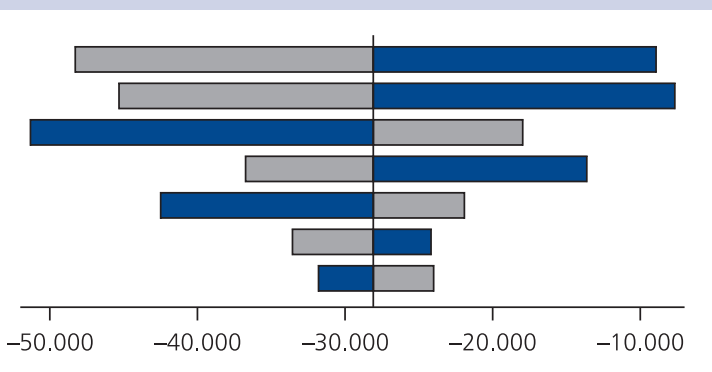

B $\square$ Upper and $\square$ Lower limit of variable value

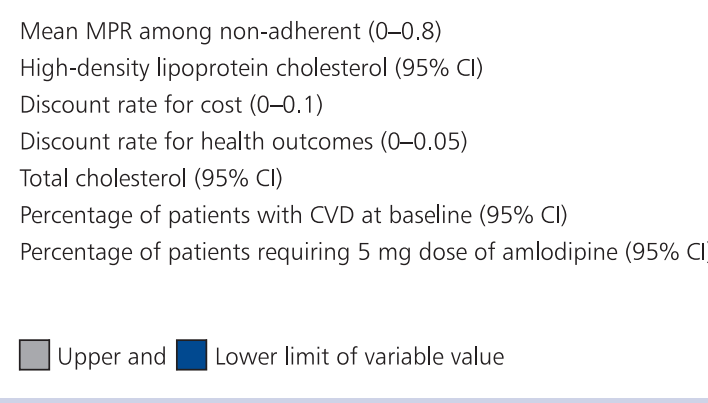

Incremental cost-utility ratio (PLN per QALY)

Figure 2. One-way sensitivity analyses of the effect of the seven key input variables on incremental cost-utility ratio from the perspective of the National Health Fund (NHF) (A) or NHF and patient (B). Negative values of incremental cost-utility ratio mean single-pill combination (SPC) dominates free combination (FC) comparator; Cl — confidence interval; CVD — cardiovascular disease; MPR — medication possession ratio; OR — odds ratio; QALY — qualy-adjusted life year

tion (direct estimation of MPR/PDC for SPCs and FCs from studies comparing those treatments) resulted in higher total cost of SPC treatment than FC from the perspective of the NHF (by 109.07 PLN) with additional health benefit. The ICUR estimated for this scenario did not exceed the WTP in Poland, indicating that the SPC treatment was cost-effective in comparison to FC treatment in all scenarios (Table 4).

\section{DISCUSSION}

The present study has estimated, based on the literature data and results of surveys among experts, the cost-utility of arterial hypertension treatment with SPC of indapamide and amlodipine in comparison with FC treatment in Polish settings.

An obvious limitation of our analysis is the lack of data directly demonstrating that the SPC of indapamide and 
Table 4. Results of key multivariate sensitivity analyses

\begin{tabular}{|c|c|c|c|c|}
\hline \multirow[t]{2}{*}{ Scenario } & \multicolumn{3}{|c|}{ With higher in adherence in SPC } & \multirow{2}{*}{$\begin{array}{c}\text { No difference in } \\
\text { adherence SPC vs. FC } \\
\text { Difference in cost from } \\
\text { perspective of NHF (NHF } \\
\text { and patient), in PLN }\end{array}$} \\
\hline & $\begin{array}{l}\text { Difference } \\
\text { in QALY }\end{array}$ & $\begin{array}{l}\text { Difference in cost } \\
\text { from perspective } \\
\text { of NHF (NHF and } \\
\text { patient), in PLN }\end{array}$ & $\begin{array}{l}\text { ICUR from } \\
\text { perspective of NHF } \\
\text { (NHF and patient) }\end{array}$ & \\
\hline Base-case scenario & 0.0208 & $-161.08(-583.71)$ & Dominant (dominant) & $-89.14(-521.69)$ \\
\hline $\begin{array}{l}\text { Alternative scenario of change in SBP on } \\
\text { treatment with SPCs vs. FCs (Bronsert et } \\
\text { al. [25]) }\end{array}$ & 0.0267 & $-217.22(-655.84)$ & Dominant (dominant) & $-89.14(-521.69)$ \\
\hline $\begin{array}{l}\text { Alternative scenario of drug utilisation } \\
\text { — direct estimation of MPR/PDC for SPCs } \\
\text { and FCs from Ferrario et al. [7], Dickson } \\
\text { et al. (PMID: 18507275), and Yang et al. } \\
\text { (PMID: 20629600) }\end{array}$ & 0.0208 & $109.07(-105.82)$ & $\begin{array}{l}5241 \text { PLN per QALY } \\
\text { saved (dominant) }\end{array}$ & $-73.96(-432.88)$ \\
\hline $\begin{array}{l}\text { Alternative scenario of utilities } \\
\text { (Ward et al. PMID: 17408535) }\end{array}$ & 0.0183 & $-161.08(-583.71)$ & Dominant (dominant) & $-89.14(-521.69)$ \\
\hline $\begin{array}{l}\text { Alternative scenario of utilities (QALY } \\
\text { losses per event from Lindgren et al. } \\
\text { PMID 17165074) }\end{array}$ & 0.0475 & $-161.08(-583.71)$ & Dominant (dominant) & $-89.14(-521.69)$ \\
\hline $\begin{array}{l}\text { Alternative scenario of utilities (utility } \\
\text { decrements from Burström et al. [35]) }\end{array}$ & 0.0160 & $-161.08(-583.71)$ & Dominant (dominant) & $-89.14(-521.69)$ \\
\hline No discounting & 0.0426 & $-326.91(-1,067.54)$ & Dominant (dominant) & $-153.87(-900.59)$ \\
\hline
\end{tabular}

FC — free combination; ICUR — incremental cost-utility ratio; LY — life year; MPR — medication possession ratio; NHF — National Health Fund PDC — proportion of days covered; PMID — PubMed-Indexed for MEDLINE; SBP — systolic blood pressure; SPC — single-pill combination; $\mathrm{QALY}$ — quality-adjusted life year

amlodipine results in higher effectiveness in comparison with FC (no clinical studies were identified that would have enabled a comparison of intervention taking into account aspects significant for public payer and/or patients, including adherence). Hence, the results of a meta-analysis for other SPCs were used in this analysis. However, the extremely conservative assumption of no difference in patients' adherence between the SPC and the FC comparator yielded essentially the same conclusions as the base-case analysis; therefore, the findings of our study seem very robust with respect to the clinical input. It is worth mentioning that the effectiveness results presented in the study could be related to the comparison of any SPC with FC; however, as we do not consider SBP achieved on the treatment with other FCs there could be some changes in the estimated number of QALY saved for SPCs of other substances (the algorithm used to obtain the amount of CVD events avoided is based on an absolute value of SBP, i.e. the sum of SBPs achieved with FC and 'gain' in SBPs from compliance boost). The cost of treatment differs between SPCs, so the results of our study could not be generalised to all SPCs.

Secondly, there was also no possibility to directly assess the influence of the analysed combined intervention on clinically significant endpoints, including the risk of cardiovascular event occurrence or deaths due to hypertension. Therefore, we used the algorithm of conversion of the SBP to clinically significant endpoints. Additionally, there are no studies carried out in Polish settings, which assess the influence of all clinical events included in this analysis on life quality. In the absence of precise and cross-sectional data, the results of the survey were used to determine the medical resources used among the study population. Data received from clinical experts was confirmed by published studies.

Despite the limitations, some results of our study, i.e. expected savings related to cost of cardiovascular events omitted as a result of the higher adherence to treatment with SPC in comparison to $\mathrm{FC}$, are reflected by the results of retrospective observational studies conducted in other settings [5-7, 29].

The impact of adherence to hypertensive treatment on health care resources utilisation and/or health outcomes were confirmed by observational studies $[23,24]$ as well as simulation studies [30, 31].

However, no prospective study was identified to date, which assesses the economic value of hypertensive treatment with SPC in comparison to FC. No economic evaluation was identified which compares the SPC with FC in any setting.

A meta-analysis of retrospective studies incorporating direct medical costs, adherence and persistence estimates 
among SPC and FC treatment was found [5]. Patients receiving SPC are more likely to be adherent to treatment (by 13.3\%; 95\% Cl 8.26-18.35\%) with more than two times longer persistence (RR 2.13; 95\% Cl 1.11-4.09) compared with FC. The influence of therapy (SPC or FC) on treatment costs was also proven (lower costs in the SPC group) [5].

Adherence and the risk of cardiovascular event occurrence in hypertensive patients treated with SPC of amlodipine and olmesartan, SPC of amlodipine and benazepril, or FC of amlodipine and ARB were assessed in study [7]. The results showed that in the FC group the risk of cardiovascular events occurrence is higher than in SPC of amlodipine and olmesar$\tan (H R 1.35, p<0.001)$. In another study it was proven that SPC therapy results in a reduction of cardiovascular events by $27 \%$ (95\% Cl 24-30\%) compared with FC [6].

A meta-analysis of four studies, carried out in the year 2007 , indicated that patients on SPC therapy have a 24\% (95\% Cl 19-29\%) lower risk of being non-adherent compared with patients on FC therapy [29].

A limited number of studies confirmed the direct influence of SPC treatment instead of FC on the risk of cardiovascular events or the risk of death due to cardiovascular events $[6,7]$. Nevertheless, some observational studies and modelling results showed the influence of adherence on the risk of cardiovascular events and/or the risk of death due to CVD.

The results of a simulation study [30] indicate that raising of the average adherence to $70 \%$ results in a decrease of cardiovascular events by $1 \%$. In another study [31] it was observed that with $100 \%$ adherence the risk of stroke, myocardial infarction, kidney disease due to hypertension, and heart disease due to hypertension was reduced by $34 \%, 27 \%$, $37 \%$, and $31 \%$, respectively.

In a study including patients with hypertension, without CVD, a reduction of annual risk of CVD by $22 \%(95 \% \mathrm{Cl}$ 13-30\%) was observed among patients adherent to treatment compared with non-adherent patients [23]. Similarly, in a study including patients with hypertension, without prior stroke [24], a reduction of risk of stroke and death by $8 \%(95 \% \mathrm{Cl} 4-13 \%)$ and $7 \%(95 \% \mathrm{Cl} 4-10 \%)$, respectively, was observed in adherent patients compared with non-adherent patients.

The improvement of hypertensive treatment in Poland undoubtedly results from greater use of SPC [32]. SPC medicines with their additional clinical benefits in the form of better adherence, stronger hypertensive effect, limited adverse events, simplification of treatment scheme, and lower costs, are becoming more and more popular among hypertensive patients [3].

The results of our study show that the treatment with SPC of indapamide and amlodipine in place of FC results in higher effectiveness and lower costs from both economic perspectives. Even with the conservative assumption of equal effectiveness of SPC and FC, outcomes of economic evaluation remained favourable to SPC (lower cost from both perspectives).

In 2013, the NHF refunded around 116,466,518 daily doses of indapamide $(2.5 \mathrm{mg} / \mathrm{d})$ and amlodipine $(5 \mathrm{or} 10 \mathrm{mg} / \mathrm{d}$ ) administrated in FC schemes. This amounted to 53.057 million PLN from an NHF perspective and around 43.868 million PLN from a patients' perspective.

The replacement of FC with SPC results in savings for both NHF perspective and NHF and patient's perspective, irrespectively of the assumption of the difference in adherence between SPC and FC. When the difference in effectiveness is neglected, the savings would amount to 3.954 million PLN and 19.186 million PLN from the NHF perspective and from the NHF and patient's perspective, respectively. When higher adherence to treatment with SPC is assumed, the total savings amount to 1.602 million PLN from the NHF perspective and 16.498 million PLN from the NHF and patients' perspective. The introduction of SPC of indapamide and amlodipine on the reimbursement list next to FC resulted also in avoidance of 598 cardiovascular events in the target patients' population (calculated based on the average annual CVD events rate from the Markov model and population size expressed as a number of patients-years). It backs up the mentioned experts' consensus of the Polish Cardiac Society and the Polish Society of Hypertension promoting SPC over FC in clinical practice [3].

The Health Technology Assessment for SPC of indapamide and amlodipine (Tertens-AM ${ }^{\circledR}$ ) had already been appraised by the Polish HTA Agency, and the drug received a positive recommendation. The AHTAPol conclusions were based on an economic analysis, but the results presented in this paper differ from HTA documentation due to another cost input (different prices of Tertens- $\mathrm{AM}^{\circledR}$ ) included in the analysis.

\section{CONCLUSIONS}

Arterial hypertension treatment with SPC of indapamide and amlodipine was found to be economically warranted, irrespective of the assumption of the economic model. The treatment with SPC dominated the FC when the difference in adherence to treatment and effectiveness were considered; SPC was less expensive than FC when the difference in effectiveness was neglected.

Treatment with SPC of indapamide and amlodipine in comparison to FC generates significant national savings from both the public payer's perspective and from the public payer's and patient's perspective, in the contemporary Polish setting. It could reduce the number of cardiovascular events among treated patients due to an increase in the adherence rate. Therefore reimbursement of this SPC from public funds is justified also from the budgetary point of view, on top of arguments focusing on clinical evidence, guidelines, and impact on patients' adherence to therapy. 
Conflict of interest: Paweł Kawalec, Przemysław Holko, Ewa Stawowczyk - preparation of economic analysis and budget impact analysis for Tertens-AM ${ }^{\circledR}$ on behalf of the Servier Polska, Łukasz Borowiec — cooperation with Servier Polska, the manufacturer of Tertens-AM ${ }^{\circledR}$.

\section{References}

1. Zdrojewski T, Wyrzykowski B, Szczech R et al. Epidemiology and prevention of arterial hypertension in Poland. Blood Press Suppl, 2005; 2: 10-16.

2. Mancia G, Fagard R, Narkiewicz K et al. 2013 ESH/ESC Guidelines for the management of arterial hypertension: the Task Force for the management of arterial hypertension of the European Society of Hypertension (ESH) and of the European Society of Cardiology (ESC). J Hypertens, 2013. 34: 2159-2219. doi: 10.1097/01.hjh.0000431740.32696.cc.

3. Wożakowska-Kapłon B, Filipiak KJ, Czarnecka D et al. Miejsce leków złożonych w terapii nadciśnienia tętniczego: aktualne problemy w Polsce. Kardiol Pol, 2013; 4: 433-438.

4. Hilleman DE. Adherence and health care costs with single-pill fixed-dose combinations in hypertension management. J Manag Care Pharm, 2014; 20: 93-100.

5. Sherrill B, Halpern M, Khan S et al. Single-pill vs. free-equivalent combination therapies for hypertension: a meta-analysis of health care costs and adherence. J Clin Hypertens (Greenwich), 2011; 13: 898-909. doi: 10.1111/j.1751-7176.2011.00550.x

6. BelseyJD. Optimizing adherence in hypertension: a comparison of outcomes and costs using single tablet regimens vs individual component regimens. J Med Econ, 2012; 15: 897-905. doi: 10.3111/13696998.2012.689792.

7. Ferrario CM, Panjabi S, Buzinec P, Swindle JP. Clinical and economic outcomes associated with amlodipine/renin-angiotensin system blocker combinations. Ther Adv Cardiovasc Dis, 2013; 7: 27-39. doi: 10.1177/1753944712470979.

8. Barrios V, Escobar C. Which thiazide to choose as add-on therapy for hypertension? Integrated Blood Press Control, 2014; 7: 35-47. doi: 10.2147/IBPC.S40248.

9. Steciwko A, Januszewicz A, Opolski G et al. Leczenie nadciśnienia tętniczego u 74745 chorych w praktyce lekarzy podstawowej opieki zdrowotnej: wyniki badania POZ-NAD. Arterial Hypertension, 2008; 12:101-108.

10. Iskenderov BG, Sisina ON, Burmistrova LF. Selection of rational combinations of indapamide with various calcium antagonists in patients with arterial hypertension. Kardiologiia, 2011; 4: 22-27.

11. James PA, Oparil S, Carter BL et al. 2014 Evidence-Based Guideline for the Management of High Blood Pressure in Adults Report From the Panel Members Appointed to the Eighth Joint National Committee (JNC 8). JAMA, 2014; 311: 507-520. doi:10.1001/jama.2013.284427.

12. Oparil S, Melino M, Lee J et al. Triple therapy with olmesartan medoxomil, amlodipine besylate, and hydrochlorothiazide in adult patients with hypertension: The TRINITY multicenter, randomized, double-blind, 12-week, parallel-group study. Clin Ther, 2010; 32: 1252-1269. doi: 10.1016/j.clinthera.2010.07.008

13. Calhoun DA, Lacourcière Y, Chiang YT, Glazer RD. Triple antihypertensive therapy with amlodipine, valsartan, and hydrochlorothiazide: a randomized clinical trial. Hypertension, 2009; 54: 32-39. doi: 10.1161/HYPERTENSIONAHA.109.131300.

14. Anderson KM, Odell PM, Wilson PW, Kannel WB. Cardiovascular disease risk profiles. Am Heart J, 1991; 121 (1 Part 2): 293-298.

15. D'Agostino RB, Wolf PA, Belanger AJ et al. Stroke risk profile: adjustment for antihypertensive medication the Framingham study. Stroke, 1994; 25: 40-43.

16. O’Donnell MJ, Xavier D, Liu L et al. Risk factors for ischaemic and intracerebral haemorrhagic stroke in 22 countries (the INTERSTROKE study) a case-control study. Lancet, 2010; 376: 112-123. doi: 10.1016/S01406736(10)60834-3.

17. Morrow DA, Antman EM, Charlesworth A et al. TIMI risk score for ST-elevation myocardial infarction: a convenient, bedside, clinical score for risk assessment at presentation: an intravenous nPA for treatment of infarcting myocardium early II trial substudy. Circulation, 2000; 102: 2031-2037. doi: 10.1161/01.CIR.102.17.2031.

18. Morrow DA. Cardiovascular risk prediction in patients with stable and unstable coronary heart disease. Circulation, 2010; 121: 2681-2691. doi: 10.1161/CIRCULATIONAHA.109.852749.

19. Howard G, Evans GW, Crouse JR et al. A prospective reevaluation of transient ischemic attacks as a risk factor for death and fatal or nonfatal cardiovascular events. Stroke, 1994; 25: 342-345.

20. Bergh C, Udumyan R, Fall K et al. Stress resilience in male adolescents and subsequent stroke risk: cohort study. J Neurol Neurosurg Psychiatry, 2014; 10: 1-6. doi: 10.1136/jnnp-2013-307485.

21. Gupta AK, Arshad S, Poulter NR. Compliance, safety, and effectiveness of fixed-dose combinations of antihypertensive agents: a meta-analysis. Hypertension, 2010; 55: 399-407. doi: 10.1161/HYPERTENSIONAHA.109.139816

22. Brixner DI, Jackson KC, Sheng X et al. Assessment of adherence, persistence, and costs among valsartan and hydrochlorothiazide retrospective cohorts in free-and fixed-dose combinations. Curr Med Res Opin, 2008; 24: 2597-2607. doi: 10.1185/03007990802319364.

23. Kettani FZ, Dragomir A, Cote R et al. Impact of a better adherence to antihypertensive agents on cerebrovascular disease for primary prevention. Stroke, 2009; 40: 213-220. doi: 10.1161/STROKEAHA.108.522193.

24. Bailey JE, Wan JY, Tang J et al. Antihypertensive medication adherence, ambulatory visits, and risk of stroke and death. J Gen Intern Med, 2010; 25: 495-503. doi: 10.1007/s11606-009-1240-1.

25. Bronsert MR, Henderson WG, Valuck R et al. Comparative effectiveness of antihypertensive therapeutic classes and treatment strategies in the initiation of therapy in primary care patients: a Distributed Ambulatory Research in Therapeutics Network (DARTNet) study. J Am Board Fam Med, 2013; 26: 529-538.

26. Golicki D, Niewada M, Jakubczyk M et al. Self-assessed health status in Poland: EQ-5D findings from the Polish valuation study. Pol Arch Med Wewn, 2010; 120: 276-281.

27. Lunde L. Can EQ-5D and 15D be used interchangeably in economic evaluations? Assessing quality of life in post-stroke patients. Eur J Health Econ, 2013; 14: 539-550. doi: 10.1007/s10198-012-0402-y.

28. De Smedt D, Clays E, Doyle F et al. Validity and reliability of three commonly used quality of life measures in a large European population of coronary heart disease patients. Int J Cardiol, 2013; 167: 2294-2299. doi: 10.1016/j.ijcard.2012.06.025.

29. Bangalore S, Kamalakkannan G, Parkar S, Messerli FH. Fixed-dose combinations improve medication compliance: a meta-analysis. Am J Med., 2007; 120: 713-719.

30. Mennini FS, Marcellusi A, von der Schulenburg JM et al. Cost of poor adherence to anti-hypertensive therapy in five European countries. Eur J Health Econ, 2015; 16: 65-72. doi: 10.1007/s10198-013-0554-4.

31. Kockaya G, Wertheimer A. Can we reduce the cost of illness with more compliant patients? An estimation of the effect of 100\% compliance with hypertension treatment. J Pharmacy Practice, 2011; 24: 345. doi: 10.1177/0897190010389336.

32. Widecka K. Jaką rolę odegrały złożone leki hipotensyjne w poprawie skuteczności leczenia nadciśnienia w Polsce? Nadciśnienie Tętnicze, 2012; 16: 187-193

33. Sullivan PW, Ghushchyan VH, Ben-Joseph R. The impact of obesity on diabetes, hyperlipidemia and hypertension in the United States. Qual Life Res, 2008; 17: 1063-1071. doi: 10.1007/s11136-008-9385-7.

34. Wang HM, Beyer M, Gensichen J, Gerlach FM. Health-related quality of life among general practice patients with differing chronic diseases in Germany: cross sectional survey. BMC Public Health, 2008; 8: 246. doi: 10.1186/1471-2458-8-246.

35. Burström K, Johannesson M, Diderichsen F. Health-related quality of life by disease and socio-economic group in the general population in Sweden. Health Policy, 2001; 55: 51-69.

Cite this article as: Kawalec P, Holko P, Stawowczyk E et al. Economic evaluation of single-pill combination of indapamide and amlodipine in the treatment of arterial hypertension in the Polish setting. Kardiol Pol, 2015; 73: 768-780. doi: 10.5603/KP.a2015.0089. 


\title{
Analiza ekonomiczna dotycząca preparatu złożonego zawierającego indapamid i amlodipinę $\mathrm{w}$ terapii nadciśnienia tętniczego w warunkach polskich
}

\author{
Paweł Kawalec ${ }^{1}$, Przemysław Holko², Ewa Stawowczyk ${ }^{3}$, Lukasz Borowiec $^{4}$, Krzysztof J. Filipiak ${ }^{5}$ \\ ${ }^{1}$ Instytut Zdrowia Publicznego, Wydział Nauk o Zdrowiu, Uniwersytet Jagielloński, Collegium Medicum, Kraków \\ ${ }^{2}$ Centrum HTA Sp. z o.o. Sp. komandytowa, Kraków \\ ${ }^{3}$ Ekspert HTA, Kraków \\ ${ }^{4}$ Dział Medyczny, Servier Polska Ltd., Warszawa \\ 5I Klinika Kardiologii, Warszawski Uniwersytet Medyczny, Warszawa
}

\section{Streszczenie}

Wstęp: Nadciśnienie tętnicze jest powszechnym schorzeniem w Polsce i dotyczy 9 mln osób dorosłych. Terapia nadciśnienia tętniczego produktami złożonymi (SPC) z dwóch lub więcej substancji cechuje się istotnymi korzyściami w porównaniu z politerapią (FC) składnikami produktu złożonego (tj. większe stosowanie się do zaleceń i wynikająca z tego lepsza kontrola nadciśnienia), które skutkują niższym ryzykiem wystąpienia zdarzeń sercowo-naczyniowych i mniejszym zużyciem zasobów medycznych. W aktualnych wytycznych ESC/ESH z 2013 r. po raz pierwszy zarekomendowano terapię skojarzoną diuretykiem i antagonistą kanału wapniowego. Obecnie żadne takie połączenie nie jest współfinansowane ze środków publicznych w Polsce. Jedynym zarejestrowanym w naszym kraju produktem złożonym indapamidu i amlodipiny jest Tertens-AM ${ }^{\circledR}$, który jest dostępny w dawkach: 1,5 mg indapamidu $+5 \mathrm{mg}$ amlodipiny oraz 1,5 mg indapamidu $+10 \mathrm{mg}$ amlodipiny. Potencjalna wielkość rynku dla produktu złożonego indapamidu i amlodipiny, oszacowana na podstawie danych refundacyjnych Narodowego Funduszu Zdrowia (NFZ), wynosi teoretycznie nawet do $13 \mathrm{mln}$ jednostek zawierających 30 dawek, a w praktyce może osiągnąć jedną trzecią tej wartości (350 tys. osób w Polsce).

Cel: Celem badania była ocena zasadności ekonomicznej leczenia produktem złożonym indapamidu i amlodipiny (Tertens-AM ${ }^{\circledR}$ ) pacjentów z nadciśnieniem tętniczym w porównaniu z politerapią indapamidem i amlodipiną w Polsce.

Metody: Wobec braku opublikowanych danych bezpośrednio oceniających dodatkowy efekt kliniczny zastosowania produktu złożonego indapamidu i amlodipiny w miejsce politerapii tymi substancjami u pacjentów z nadciśnieniem tętniczym, w analizie ujęto dwa podejścia: pierwsze uwzględnia różnice w efektywności wynikające z lepszego stosowania się do zaleceń (adherence), oszacowane na podstawie opublikowanego badania dla innych molekuł stosowanych w terapii nadciśnienia — analiza podstawowa (1) oraz drugie zakładające brak różnic w efektywności lub stosowaniu się do zaleceń między SPC i FC indapamidu z amlodipiną — podejście konserwatywne (2). Populację badaną stanowili pacjenci zgodni z zarejestrowanym wskazaniem do stosowania produktu Tertens-AM ${ }^{\circledR}$ (leczenie substytucyjne osób z nadciśnieniem tętniczym samoistnym, którzy stosują indapamid i amlodipinę w takich samych dawkach w oddzielnych preparatach). Wejściowe dane kliniczne oszacowano na podstawie literatury, a w przypadku ich braku wykorzystano odpowiedzi ekspertów z 4 ośrodków klinicznych w Polsce. Modelowanie przeprowadzono na podstawie modelu Markowa, w dożywotnim horyzoncie czasowym. Obserwacji poddano dwie hipotetyczne grupy (SPC i FC) z nadciśnieniem tętniczym. W modelu założono modyfikację schematu leczenia (dodanie antagonisty receptora angiotensyny do aktualnego schematu terapii) w przypadku braku kontroli skurczowego ciśnienia tętniczego po założonym okresie czasu. Charakterystykę pacjentów skorelowano z ryzykiem zdarzeń związanych z chorobą układu sercowo-naczyniowego, wykorzystując algorytmy predykcji z badania Framingham Heart Study. W celu oceny różnicy w stosowaniu się do zaleceń między SPC i FC przeprowadzono aktualizację metaanalizy Gupta et al., która wykazała, że prawdopodobieństwo stosowania się do zaleceń jest większe w przypadku SPC w porównaniu z FC (iloraz szans:

\section{Adres do korespondencji:}

dr n. med. Paweł Kawalec, Instytut Zdrowia Publicznego, Wydział Nauk o Zdrowiu, Uniwersytet Jagielloński, Collegium Medicum, ul. Grzegorzecka 20, 31-531 Kraków, e-mail: mxpkawal@cyf-kr.edu.pl

Praca wpłynęła: 22.12.2014 r. Z Zaakceptowana do druku: 31.03.2015 r. $\quad$ Data publikacji AoP: 28.04.2015 r. 
$\mathrm{OR}=1$,68). Prawdopodobieństwo stosowania się do zaleceń w przypadku FC zostało określone na podstawie metaanalizy badań obserwacyjnych, natomiast w przypadku SPC wykorzystano analogiczne dane skorygowane o wartość OR. Z powodu braku danych umożliwiających ilościową korelację poziomu stosowania się do zaleceń z wynikami zdrowotnymi, uwzględniono ciśnienie skurczowe jako jedyny predyktor różnicy w wynikach zdrowotnych między pacjentami SPC i FC. Do oceny jakości życia wykorzystano dane dla populacji ogólnej w Polsce oraz informacje o redukcji jakości życia wynikającej z wystąpienia uwzględnionych w analizie zdarzeń klinicznych. Koszty oszacowano z perspektywy płatnika publicznego (NFZ) oraz płatnika publicznego i pacjenta. Wzięto pod uwagę tylko bezpośrednie koszty medyczne. W ocenie kosztów farmakoterapii amlodipiną $\mathrm{i}$ indapamidem uwzględniono wyłączenie preparaty refundowane w odpowiedniej dawce (1,5 mg w przypadku indapamidu i 5 lub 10 mg w przypadku amlodipiny). Koszt produktu Tertens-AM ${ }^{\circledR}$ określono na podstawie średniej ceny detalicznej w lipcu 2014 r. Założono współfinansowanie ocenianego produktu w ramach osobnej grupy limitowej, z 30-procentową odpłatnością pacjenta do wysokości limitu finansowania. Zużycie zasobów medycznych przez chorych z analizowanej populacji określono na podstawie wyników badania kwestionariuszowego przeprowadzonego wśród ekspertów klinicznych z 4 ośrodków w Polsce. W ramach analizy ekonomicznej określono lata życia skorygowane o jakość oraz koszty całkowite z obu uwzględnionych perspektyw dla stosowania SPC i FC indapamidem oraz amlodipiną.

Wyniki: Leczenie SPC indapamidu i amlodipiny w miejsce FC wiąże się z uzyskaniem dodatkowych 7,6 dnia życia w pełnym zdrowiu oraz dłuższym o 2,9 dnia przeżyciem. Stosowanie SPC okazało się tańsze w porównaniu z FC zarówno z perspektywy płatnika publicznego, jak i płatnika publicznego oraz pacjenta. Zastosowanie SPC w miejsce FC będzie się wiązać z oszczędnościami z perspektywy płatnika publicznego oraz pacjenta, zarówno w przypadku braku uwzględnienia, jak i uwzględnienia różnic w skuteczności klinicznej między SPC i FC. Oszczędności wyniosą 1,602-3,954 mln PLN oraz 16,498-19,186 mln PLN, odpowiednio z perspektywy płatnika publicznego oraz pacjenta.

Wnioski: Stosowanie SPC indapamidu i amlodipiny u pacjentów z nadciśnieniem tętniczym dominuje nad FC, przy założeniu różnic w efektach zdrowotnych lub jest tańsze w odniesieniu do FC w przypadku pominięcia różnic w efektach zdrowotnych. Zastosowanie SPC w miejsce FC będzie się wiązać z oszczędnościami z perspektywy płatnika publicznego oraz pacjenta, zarówno w przypadku uwzględnienia, jak i braku uwzględnienia różnic w skuteczności klinicznej.

Słowa kluczowe: indapamid, amlodipina, produkt złożony, ekonomika zdrowia, analiza kosztów-użyteczności, analiza wpływu na budżet

Kardiol Pol 2015; 73, 9: 768-780 